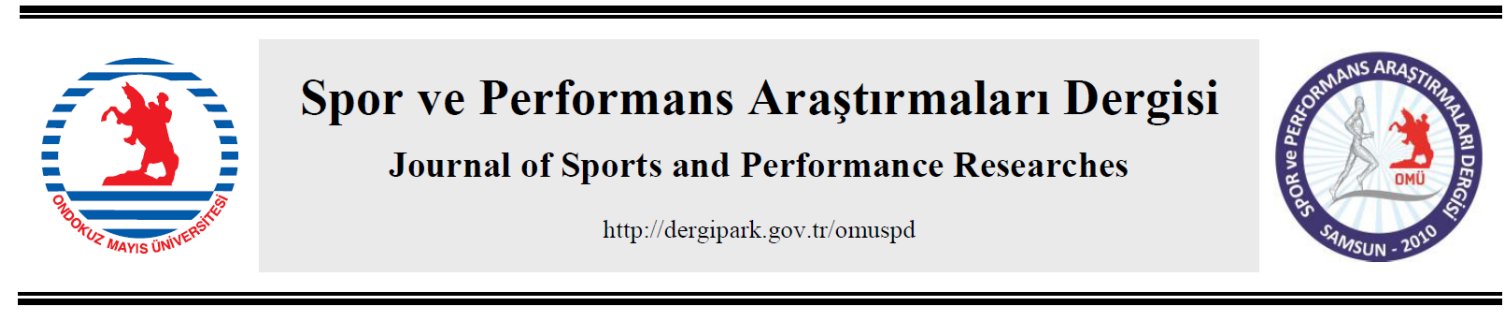

Araştırma Makalesi

Geliş Tarihi/Received : 22.05.2019

Kabul Tarihi/Accepted : 09.04.2020

DOI: $10.17155 / o m u s p d .569086$

\title{
INVESTIGATION OF SUPERSTITIOUS BEHAVIOR OF AMATEUR FOOTBALL PLAYERS
}

\author{
Hüseyin ÖZTÜRK ${ }^{1}$
}

\begin{abstract}
This study has been prepared to examine the superstitious behaviors of amateur footballers. The study sample consists of 389 (45 female, 335 male) sportsmen playing amateur football in the Gaziantep province in 2018. Statistical analyzes were performed on data obtained in the study by using the SPSS 22.0 package program. Statistical methods such as frequency, percentage, mean, standard deviation were used for evaluating data as well as t-test for two independent groups and ANOVA and LSD multiple comparison tests for comparison of two independent groups.

As a result of the study, it was found that there is a significant difference between amateur football player's gender variable and lucky objects, behaviors before game, behaviors during game, team behaviors sub dimensions and total superstitious belief scale; between age variable and dressing style/appearance, lucky objects, behaviors during game, team behaviors, prayer and total superstition scale score and between in year variable and lucky objects sub-dimension.
\end{abstract}

Keywords: Amateur, Footballer, Belief, Behavior.

\section{AMATÖR FUTBOLCULARIN BATIL INANÇ DAVRANIŞLARININ INCELENMESI}

\section{ÖZET}

Bu çalışma amatör futbolcuların batıl inanç davranışlarını incelemek amacı ile hazırlanmıştır. Araştırma örneklemini 2018 yılında Gaziantep ilinde amatör futbol oynayan toplam 389 (45 kadın, 335 erkek) sporcu oluşturmaktadır. Araştırmada elde edilen verilerin SPSS 22.0 paket programından yararlanılarak istatistiksel analizleri yapılmıştır. Verilerin değerlendirilmesinde istatistik yöntem olarak; frekans, yüzde, ortalama, standart sapma, iki bağımsız gruplar için t-testi ve ikiden fazla bağımsız grubun karşılaştırılmasında ANOVA ve LSD çoklu karşılaştırma testleri kullanılmıştır.

Araştırma sonucunda; amatör futbolcuların cinsiyet değişkeni ile uğurlu sayılan nesneler, oyun karşılaşma öncesi, oyun sırası, takım davranımları alt boyutları ve toplam batıl inanç puanıyla anlamlı fark olduğu $(p<0,05)$, yaş değişkeni ile giyim/görünüş, uğurlu sayılan nesneler, oyun karşılaşma sırasında, oyun sırasında, takım sırası, takım davranımları, dua etme ve toplam batıl puanıyla ve yıl değişkeni ile uğurlu sayılan nesneler alt boyutunda anlamlı fark olduğu görülmektedir $(p<0,05)$.

Anahtar Kelimeler: Amatör, Futbolcu, İnanç, Davranış.

\footnotetext{
Gaziantep University, Physical Education And Sport Science Department, Gaziantep, Turkey. Yazışmadan sorumlu yazar: ozturkavrasya@hotmail.com 


\section{INTRODUCTION}

Since the beginning of mankind, people in all societies have believed in supernatural events that have no grounds in reality usually due to their fears, despair and old traditions. These beliefs are called superstitions. Beliefs and behaviors without a logical basis are called superstitious beliefs. According to another view, superstition is the sum of beliefs or habits originating from ignorance, fear of the unknown, belief in luck or interpretation of reason [1]. It is defined as an irrational belief in supernatural events, hidden and irrational powers, and prophecies [2].

Superstition is defined as a false, fallacious, unfounded set of empty beliefs [3]. Throughout the ages, people have exhibited behaviors which are appropriate to the cultural tapestry of the societies they live in and which are not grounded in reality but still believed in by many in order to turn to their advantage events that they cannot bring under their control [4]. People have always searched for mysterious things and believed that there are supernatural beings which can exert influence on their lives [5].

Together with the belief principles of religions, people made an effort to draw conclusive conclusions from incidental events that contradict religious dogmatism and to lead many unexplained beliefs [6]. Although superstition is false, it empowers people to believe that they can influence the outcome of events that they cannot really control [7]. Although there is no causal relationship between superstitious behaviors and their consequences, people perceive their unusual, repetitive and inflexible actions as having a positive impact [8].

Superstition is the tendency to attribute natural events to supernatural forces. It represents an effort on the part of people to try to convert uncontrollable forces into controllable forces [9]. It means claiming that there exists a relationship between emotions and objects that have no causal relationship with each other [10]. One of the areas where superstitious behaviors are most easily observable is sports. Historically, superstitious behaviors have been observed among sportsmen, stretching on a large spectrum from elite all the way down to amateur athletes. In addition, many elite athletes in different branches have their own superstitious behaviors. Furthermore, sportsmen from different branches can exhibit different superstitious behaviors. 
This is, of course, expected behavior, but if one were to find a common reason behind such behaviors, it would be the fear of losing and the ambition to win. For all these reasons, there are many scientific studies examining superstitious behaviors [11-13]. Superstitious behaviors are seen as a way of reducing the anxiety of sportsmen and it is also observed that athletes with higher egos have higher levels of anxiety. It has been determined that there is a positive relationship between superstitious beliefs and anxiety in most of the studies conducted [12].

This study intends to reveal whether the athletes who actively play amateur football exhibit tendencies of superstitious behavior and at the same time to determine the extent to which superstitious beliefs have an impact on their achievements and daily lives.

\section{MATERIALS and METHODS}

\section{Study Population and Sample}

The study population is comprised of sportsmen playing football in amateur clubs in Gaziantep province. Personal data belonging to individuals covered by the study are given in Table 1.

The random sampling method has been used when choosing the samples [13]. Through random sampling, 379 (45 female, 334 male) persons have been included in the sampling. The study has been conducted with amateur footballers in Gaziantep who agreed to participate in the study.

Table 1. Personal information belonging to the study group

\begin{tabular}{llll}
\hline Groups & & $\mathbf{F}$ & $\mathbf{\%}$ \\
\hline \multirow{3}{*}{ Age (year) } & $12-16$ & 39 & 10.3 \\
\cline { 2 - 4 } & $17-22$ & 232 & 61.2 \\
\cline { 2 - 4 } & 23 and above & 108 & 28.5 \\
\hline \multirow{3}{*}{ Gender } & Female & 45 & 11.9 \\
\cline { 2 - 4 } Football Experience (year) & Male & 334 & 88.1 \\
\hline
\end{tabular}
$\mathrm{n}=379$

As can be inferred from Table 1, those who participated in the survey are mostly in the age bracket of $17-22$ years (61.2\%) (232 persons), mostly male (88.1\%) (334 persons). 


\section{Data Collection Tools}

The Turkish adaptation of the inventory of superstitious beliefs and behaviors (Superstitious Ritual Questionnaire) developed by Buhrmann and Zaugg [14] was made by Barut (2008). In order to test the reliability of the scale, the Cronbach Alpha internal consistency coefficient was checked and found to be 0.95 [15]. The Cronbach Alpha internal consistency coefficient was found to be 0.98 in this study. The scale is made up of 37 items, has a 5 point likert-type design and consists of 6 sub-dimensions. These are, respectively, Dressing style and Appearance (8 items), Lucky Objects (6 items), Behaviors Before the Game, (11 items), Behaviors During the Game (3 items), Team Behaviors (2 items) and Praying ( 3 items). The sportsmen were asked to rate the extent to which these factors have an impact on their sporting careers by using the responses; (1) Not effective at all, (2) Somewhat effective (3), Occasionally effective (4), Effective (5) Very effective.

\section{Analysis of the Data}

Statistical analysis of the data has been performed with SPSS 22.0 program. In the study, the "KMO" analysis has been performed to test the sample size. Accordingly, it was seen that the KMO (Kaiser-Meyer-Olkin) test was greater than $0.60(0.820)$ and Bartlett test was significant $(p<0.001)$. Therefore, the sample is sufficient and the existence of a structure is detectable. Reliability coefficients of the superstition scale were examined and it was determined that the scale was reliable, with Cronbach alpha value being as high as 0.98.

The Kolmogorov-Smirnov test was used in the conformity check of continuous variables to normal distribution for data analysis. The $t$ test was used to compare two independent groups of variables with normal distribution, and ANOVA and LSD multiple comparison tests were used for variables with normal distribution in the comparison of two independent groups, and frequency, percentage and mean values were given as descriptive statistics. $\mathrm{P}$ $<0.05$ was accepted as significant in the statistical analyses performed in the study. 


\section{RESULTS}

Table 2. Comparison of Superstition Scale Scores by Gender

\begin{tabular}{|c|c|c|c|c|c|c|}
\hline Factor & Gender & $\mathbf{N}$ & Average & Sd & $\mathbf{t}$ & $\mathbf{P}$ \\
\hline \multirow[t]{2}{*}{ 1. Dressing style, Appearance } & Female & 45 & 2.12 & 0.56 & 1.95 & \multirow{2}{*}{0.51} \\
\hline & Male & 334 & 1.96 & 0.50 & & \\
\hline \multirow[t]{2}{*}{ 2. Lucky Objects } & Female & 45 & 1.68 & 0.60 & 4.37 & \multirow{2}{*}{$0.00^{*}$} \\
\hline & Male & 334 & 2.33 & 0.98 & & \\
\hline \multirow[t]{2}{*}{ 3. Before Game } & Female & 45 & 1.66 & 0.60 & 4.37 & \multirow{2}{*}{$0.00^{*}$} \\
\hline & Male & 334 & 2.29 & 0.76 & & \\
\hline \multirow[t]{2}{*}{ 4. During Game } & Female & 45 & 1.39 & 0.64 & 6.02 & \multirow{2}{*}{$0.00^{*}$} \\
\hline & Male & 334 & 2.42 & 1.08 & & \\
\hline \multirow[t]{2}{*}{ 5.Team Behaviors } & Female & 45 & 2.91 & 1.02 & 5.21 & \multirow{2}{*}{$0.00^{*}$} \\
\hline & Male & 334 & 1.98 & 1.13 & & \\
\hline \multirow[t]{2}{*}{ 6.Praying } & Female & 45 & 3.24 & 1.41 & 0.63 & \multirow{2}{*}{0.53} \\
\hline & Male & 334 & 3.10 & 1.35 & & \\
\hline \multirow[t]{2}{*}{ Total Score } & Female & 45 & 1.91 & 0.44 & 4.22 & \multirow{2}{*}{$0.00^{*}$} \\
\hline & Male & 334 & 2.24 & 0.49 & & \\
\hline
\end{tabular}

$p<0.05$

When Table 2 was examined, it was seen that there was a statistically significant difference between the Superstition Scale scores of amateur sportsmen ( $t=4.22, p<0.05$ ) according to the variable of gender, and that there was a significant difference between the scores from the sub-dimension of Lucky Objects $(t=4.37, p<0.05)$, behaviors before the game $(t=4.37, p<0.05)$, behaviors during the game $(t=6.02, p<0.05)$, and Team Behaviors $(t=5.21$, $p<0.05)$ while no statistically significant difference was found between scores from the lower dimension of Dressing Style, Appearance $(t=1.95, p>0.05)$ and Praying $(t=0.63, p>0.05)$ and gender.

Accordingly, male players scored higher points in comparison to female players in the lower dimension of lucky objects, behaviors before the game and behaviors during the game. 
Table 3. Comparison of Superstition Scale Scores by Age

\begin{tabular}{|c|c|c|c|c|c|c|c|c|}
\hline Factor & Age & $\mathbf{N}$ & Average & Sd & Df & $\mathbf{F}$ & $\mathbf{P}$ & $\begin{array}{l}\text { Significant } \\
\text { Difference }\end{array}$ \\
\hline & (a) Age 12-16 & 39 & 1.79 & 0.56 & 2 & & & \\
\hline 1. Dressing style, & (b) Age 17-21 & 232 & 1.98 & 0.47 & 376 & 4.00 & $0.02^{*}$ & $a<c$ \\
\hline \multirow[t]{2}{*}{ Appearance } & (c) 22 and above & 108 & 2.05 & 0.54 & 378 & & & \\
\hline & (a) Age 12-16 & 39 & 1.85 & 0.57 & & & & \\
\hline \multirow[t]{3}{*}{ 2. Lucky Objects } & (b) Age 17-21 & 232 & 2.33 & 1.01 & & 4.07 & $0.01 *$ & $a<b$ \\
\hline & (c) 22 and above & 108 & 2.25 & 0.96 & & & & \\
\hline & (a) Age 12-16 & 39 & 1.59 & 0.66 & & & & \\
\hline \multirow[t]{3}{*}{ 3. Before Game } & (b) Age 17-21 & 232 & 2.30 & 0.80 & & 15.0 & $0.00 *$ & $a<b, a<c$ \\
\hline & (c) 22 and above & 108 & 2.27 & 0.65 & & & & \\
\hline & (a) Age 12-16 & 39 & 1.87 & 1.16 & & & & \\
\hline \multirow[t]{3}{*}{ 4. During Game } & (b) Age 17-21 & 232 & 2.30 & 1.21 & & 3.76 & $0.02^{*}$ & $a<b$ \\
\hline & (c) 22 and above & 108 & 2.27 & 0.95 & & & & \\
\hline & (a) Age 12-16 & 39 & 2.83 & 1.37 & & & & \\
\hline \multirow[t]{3}{*}{ 5.Team Behaviors } & (b) Age 17-21 & 232 & 2.06 & 1.12 & & 13.2 & $0.00 *$ & $a>b, a>c$ \\
\hline & (c) 22 and above & 108 & 1.88 & 1.06 & & & & \\
\hline & (a) Age 12-16 & 39 & 3.13 & 1.58 & & & & \\
\hline \multirow[t]{3}{*}{ 6.Praying } & (b) Age 17-21 & 232 & 3.25 & 1.32 & & 6.25 & $0.03^{*}$ & $b>c$ \\
\hline & (c) 22 and above & 108 & 2.84 & 1.36 & & & & \\
\hline & (a) Age 12-16 & 39 & 3.13 & 1.88 & & & & \\
\hline \multirow[t]{2}{*}{ Total score } & (b) Age 17-21 & 232 & 3.25 & 2.26 & & 10.0 & $0.00 *$ & $a<b, a>c, b>c$ \\
\hline & (c) 22 and above & 108 & 2.84 & 2.21 & & & & \\
\hline
\end{tabular}

When Table 3 was examined, it was found that those who were in the age range of 12-16 years scored higher points than those in the age range of 17-21 and lower points than those in the age of 22 and above, and those who were in the age range of 17-21 scored higher points than those in the age range of 22 and above on the basis of total scores.

Those who were 22 years old and above have scored higher points in the sub-dimension of Superstition, Dressing Style, and Appearance than those who were in the age bracket of 1216 years.

Those who were in the age bracket of 17-21 years old have scored higher points in the sub-dimension of Superstition and Lucky Objects than those who were in the age bracket of 12-16 years. Those who were in the age bracket of 17-21 years old as well as those who were 22 years old and above have scored higher points in the sub-dimension of Superstition and Behaviors Before Game than those who were in the age bracket of 12-16 years.

Those who were in the age bracket of 17-21 years old have scored higher points in the sub-dimension of Superstition and Behaviors During the Game than those who were in the age bracket of 12- 16 years. Those who were in the age bracket of 12-16 years and 17-21 years as well as those who are were 22 years old and above have scored higher points in the 
sub-dimension of Superstition and team behaviors. Those who were in the age bracket of 17-21 years old have scored higher points in the sub-dimension of Superstition and Praying than those who were 22 years old and above. According to these findings, it has been determined that the superstitious beliefs of amateur football players change according to their ages.

Table 4. Comparison of Superstition Scale Scores by Years

\begin{tabular}{|c|c|c|c|c|c|c|c|}
\hline Factor & Age & $\mathbf{N}$ & Average & Sd & $\mathbf{F}$ & $\mathbf{P}$ & $\begin{array}{l}\text { Significant } \\
\text { Difference }\end{array}$ \\
\hline & (a) 1-3 years & 73 & 2.01 & 0.44 & & & \\
\hline 1. Dressing & (b) 4-6 years & 154 & 1.97 & 0.47 & 0.15 & 0.86 & \\
\hline \multirow[t]{2}{*}{ style, Appearance } & (c) 7 and above & 152 & 1.97 & 0.59 & & & \\
\hline & (a) 1-3 years & 73 & 2.05 & 0.80 & & & \\
\hline \multirow[t]{3}{*}{ 2. Lucky Objects } & (b) 4-6 years & 154 & 2.21 & 0.96 & 3.64 & $0.02 *$ & $a<c$ \\
\hline & (c) 7 and above & 152 & 2.40 & 1.02 & & & \\
\hline & (a) 1-3 years & 73 & 2.15 & 0.68 & & & \\
\hline \multirow[t]{3}{*}{ 3. Before Game } & (b) 4-6 years & 154 & 2.21 & 0.80 & 0.45 & 0.63 & \\
\hline & (c) 7 and above & 152 & 2.25 & 0.77 & & & \\
\hline & (a) 1-3 years & 73 & 2.22 & 1.00 & & & \\
\hline \multirow[t]{3}{*}{ 4. During Game } & (b) 4-6 years & 154 & 2.25 & 1.12 & 0.74 & 0.47 & \\
\hline & (c) 7 and above & 152 & 2.38 & 1.09 & & & \\
\hline & (a) $1-3$ years & 73 & 2.08 & 1.14 & & & \\
\hline \multirow[t]{3}{*}{ 5.Team Behaviors } & (b) 4-6 years & 154 & 2.11 & 1.13 & 0.04 & 0.96 & \\
\hline & (c) 7 and above & 152 & 2.07 & 1.16 & & & \\
\hline & (a) 1-3 years & 73 & 2.82 & 1.36 & & & \\
\hline \multirow[t]{3}{*}{ 6.Praying } & (b) 4-6 years & 154 & 3.28 & 1.37 & 2.96 & 0.53 & \\
\hline & (c) 7 and above & 152 & 3.12 & 1.36 & & & \\
\hline & (a) 1-3 years & 73 & 2.12 & 0.42 & & & \\
\hline \multirow[t]{2}{*}{ Total Score } & (b) 4-6 years & 154 & 2.20 & 0.52 & 1.59 & 0.20 & \\
\hline & (c) 7 and above & 152 & 2.25 & 0.50 & & & \\
\hline
\end{tabular}

According to Table 4, those with a sporting career of 7 years and above have scored higher points in the sub-dimension of Superstition and Lucky Objects than those with a sporting career of 1-3 years. There are no significant differences in other sub-dimensions. According to these findings, amateur footballers who have been playing for 4-6 years prefer wearing lucky objects (good-luck charms, evil eye talisman, wristbands) more in comparison to those who have been playing for 1-3 years on the basis of the Lucky Objects subdimension.

\section{DISCUSSION and CONCLUSION}

Significant differences were observed in the Superstition Scale in terms of gender. When the studies are reviewed, a study by Barut titled "the Relationship between Superstitious Behaviors and Self-Efficacy" shows a statistically significant difference in 
superstitious behavior by gender, which is similar to the findings of this study [15]. A study by Buhrman, Brown and Zaugg found significant results in terms of gender [16], too. Bicer's study titled "Pre-Competition Mystical Traditional Religious Beliefs and Relaxation Methods" has also found that the results differ significantly by gender [17]. Vyse's study has shown that there is a relationship between superstitious tendencies and gender differences [18]. Wagner has concluded that there was a significant difference between superstition and gender in a study "examining the socio-psychological connections of superstitious beliefs held by college students" [19].

A study by Preece and Baxter has also concluded that there is a significant difference in superstitious beliefs by gender [20]. A study by Kose and Ayten on the "relationship between gender and superstition" has shown that women are more likely to hold superstitious beliefs and believe in supernatural events than men [21]. In a study conducted by Safaei and Khodabakhshi, it was found that the level of tendency of women to hold superstitious beliefs was higher than that of males [22]. Sjorup and Christensen have emphasized that women suffer moral deterioration because they are more prone to superstitious beliefs than men, particularly those existing under the cover of religion [23]. A study by Wiseman and Watt has shown that women tend to be more superstitious than men [24].

A study by Isık et. al titled "Investigation of the Relationship between Superstitious Tendencies and Anxiety Levels in University Students" who are "Actively Engaged in Sports" has, on the other hand, found no significant difference in tendencies towards superstitious beliefs on the basis of gender [4]. Other similar studies which have found no significant difference are [25-28].

Superstitious tendencies of the participants of the survey show significant differences on the basis of the age variable. When the studies are reviewed, a study titled A Trial on Heterodox Faith and Behavior Scale conducted by Karaca found a significant relationship between age and superstition, which is consistent with the results obtained in this study [29]. A study by Kiray titled Eregli, a Beach Town before the Arrival of Heavy Industry, found a significant relationship between age and superstition [30]. A study by Conklin reveals that young people tend to be just as superstitious as the elderly [31]. 
Ozgüven's study on the Relationship between Superstitious Beliefs and Life Satisfaction has different findings: A study conducted in İmir found no significant relationship between age and superstitious beliefs [32]. There was no significant difference in the Superstition scale and Lucky Objects on the basis of the years the survey participants spent in their sports career. Different from the findings of this study, Bleak and Frederich concluded that there was a significant difference between the number of years spent doing sports in terms of the frequency of superstitious behavior development [33]. A study conducted by Barut found that there was a statistically significant difference in terms of the number of years spent doing sports and the frequency of superstitious behavior [14].

We have found that amateur footballers hold superstitious beliefs, and that they make superstitious beliefs a part of their lives to alleviate stress before the games and increase their chances of winning, thinking that such beliefs will bring them luck.

\section{REFERENCES}

1. Bandura A. Self Efficacy: The exercise of Control, New York, Freeman;1997.

2. Ayhan I, Yarar F. Psychology of Superstitions, Pivolka, 2005;4(17): 15-19.

3. Turkish Language Institution Turkish Dictionary. Ankara, Turkish Language Association Publications; 2002.

4. Isık U, Agbuga B, Elci G. Examining the Relationship between Superstitious Behavior in Sport and Trait Anxiety Levels among College Students Engaged in Active Sports, Sports View: Journal of Sports and Educational Sciences, 2015; 2(1): 31-39

5. Hutehison JA, Martin JA. Ways of FaiJh (An Introduction to Religion), The Ronald Pess Company, New York; 1953.

6. Schmidt W. The Origin and Growth of Religion, Trans: Rose, RI, Methuen \&Co.Ltd., London, Second Edition, London; 1935.

7. Rudski J. The Illusion Of Control, Superstitious Belief, And Optimism. Current Psychology: Developmental, Learning, Personality, Socia, 2004; 22(4): 306-315

8. Womack M. Why athletes need ritual: A study of magic among professional athletes. In: Shirl Hoffman. Ed. Sport and Religion, Champaign, IL: Human Kinetics; 1992.

9. Burger JM, Lynn AL. Superstitious Behavior Among American And Japanese Baseball Players, Basic and Applied Social Psychology, 2005; 27: 71-76.

10. Maller JB, Lunden GE. Sources of superstitious beliefs. Journal of Education Research, 1993; 26: 321-43.

11. Gmelch G. Magic in Professional Baseball, Dans G. P. Stone (Ed.), Games, Sport And Power, New Brunswick, New Jersey, 1972; 128-137.

12. Van Raalte JL, Brewer BW, Nemeroff CJ, Linder DE. Chance Orientation and Superstitious Behavior On The Putting Green. Journalof Sport Behavior, 1991;4: 41-50. 
13. Todd M, Brown C. Characteristics Associated With Superstitious Behavior In Track And Field Athletes: Are There NCAA Divisional Level Differences, Journal of Sport Behavior, 2003;26: 168-187.

14. Buhrmann H, Brown B, Zaugg M. Superstitious Beliefs And Behavior: A. Comparison of Male And Female Basketball Players. Journal of Sport Behavior 1982; 5:175-185.

15. Barut Al. Relation of superstitious behavior in sport and self-efficacy, Master Thesis, Mersin University Institute of Health Sciences, Physical Education and Sports, Mersin, 2008

16. Buhrmann HG, Zaugg MK. Superstitious among basketball players: An investigation of various forms of superstitious beliefs and behavior among competitive Basketballers at the junior high to university level. Journal of Sport Behavior, 1981; 4: 163-174.

17. Bicer AM. The Pre-competition Relaxation Methods, Superstitions and Traditional Religious Beliefs, , Gazi University Institute of Educational Sciences Department of Physical Education and Sports, Ankara; 2009.

18. Vyse SA. Believing In Magic: The Psychology Of Superstition, New York, Oxford University Press; 1997.

19. Wagner ME. Superstitions and Their Social and Psychological Correlatives, Among College Students, Journal of Educational Sociology, 2009; 2(1): 26-36.

20. Preece PFW, Baxter JH. Scepticismand gullibility: the super stitiousand pseudo-scientific beliefs of secondary school students, 2000; 22(11): 1147-1156.

21. Kose A, Ayten A. A Psycho-Sociological Analysis of Superstitious Beliefs and Rituals,Journal of Religious Studies Academic Research, 2009;9(2): 45-70.

22. Safaei S, Khodabakhshi A. A study of sociological factors of superstitions. Universal Journal of Education and General Studies, 2012;1(8): 242-252

23. Sjorup L, Christensen HR. Pieties Gender. Netherlands: Koninklijke Brill; 2002.

24. Wiseman R, Watt C. Measuring superstitious belief: Why lucky charms matter. Personality and Individual Differences, 2004;37: 1533-1541.

25. Wolfradt U. Dissociative Experiences, Trait Anxiety And Paranormal Beliefs. Personality and Individual Difference, 1997; 34: 15-19.

26. Znebb BJ, Moore MC. Super stitiousness and perceived anxiety control as predictors of psychological distress. Anxiety Disorders, 2013; 1(7): 115-130.

27. Shermer M. Why People Believe Weird Things. New York: Henry Holt and Company; 2002

28. Sica C, Novara C, Sanavio E. Culture and Psycopathology: Superstition And ObsessiveCompulsive Cognitions And Symptoms In A Non-Clinical Italian Sample, Personality and Individual Differences, 2002;32: 1001-1012.

29. Karaca F. An Essay on the Hatering Beliefs and Behaviors Scale, Journal of ilehiyat Researces, 2001;25: 145-168.

30. Kıray MB, Eregli A. Beach Town Before Heavy Industry, 3rd edition, Istanbul Baglam Publications; 2000.

31. Conklin ES. Superstitious belief and practice among college students, The American Journal of Psychology, 1919;30(1): 83-102.

32. Ozgüven N. Relationship Superstition Beliefs And Life Satisfaction: Uludag Journal of Economy and Society, 2012; 31(2): 59-73. 
Spor ve Performans Araştırmaları Dergisi Journal of Sports and Performance Researches 2020;11(1):35-45

Hüseyin ÖZTÜRK

33. Bleak JL, Frederick CM. Superstitious behavior in sport: Levels of effectiveness and determinants of use in the three collegiate sports. Journal of Sport Behavior,1998; 21: 1-15. 